\title{
GAP Analysis of Good Manufacturing Practice on Lobster Supply Chain in Lombok
}

\author{
Hamdanul Fain \\ Departement of Aquatic \\ Product Technology \\ Bogor Agricultural University \\ Bogor, Indonesia
}

\author{
Ruddy Suwandi \\ Departement of Aquatic \\ Product Technology \\ Bogor Agricultural University \\ Bogor, Indonesia
}

\author{
Tri Wiji Nurani \\ Departement of Fisheries \\ Resources Utilization \\ Bogor Agricultural University \\ Bogor, Indonesia
}

\begin{abstract}
Lobster is one of the fishery commodities to develop. The implementation of a good manufacturing practice (GMP) is important. The level of implementation of GMP in the lobster supply chain in Lombok is unknown. Therefore, a gap analysis is needed for the application of GMP in the lobster supply chain in Lombok. The application of Good Aquaculture Practice (GAP) at the level of enlargement fisher and Good Handling Practice (GHP) at the level of catchers is included in category C or quite well. In the same case the collectors level is in category A or very good. The application of Good Transportation Practice (GTP) in lobster supply chain in Lombok is quite well. However, improvements in the application of GAP, GHP, and GTP are required. Improvement in GTP is included in improvement of GAP and GHP.
\end{abstract}

Keywords: lobster; handling; aquaculture; fishermen; improvement; good manufacturing practice

\section{INTRODUCTION}

Lobster is one of the economically valuable fishery commodities. The export value produced can reach US \$ 11 777954 per year (KKP RI, 2012). Lobster prices doubled in 2015 compared to 2009 which originally sold for 150000 per kilogram. This increase in selling prices is an opportunity for fishermen in East Lombok, West Nusa Tenggara. Lobster production in this area reached 146 tons in 2011. Although in the following years it decreased to 47.9 tons in 2014. Opportunities to maximize production can be seen from the many available seeds in Lombok waters. Jones et al (2010) reported that in Lombok had two peak harvest seasons of lobster seeds (puerulus phase), namely in August-September and April-May. The lowest number of seeds is 25000 and the highest number is 70000 . Increased production is supported by the existence of the PERMEN KP No 1 of 2015 which requires a minimum size of lobster exports so that export of seeds is not allowed. Thus the fishermen are very helpful to get lobster seeds.

Putro (2008) states that aspects of quality and food safety have an important role in supporting export competitiveness. The quality aspect of lobster depends on how it is handled along the lobster supply chain. The implementation of a good manufacturing practice (GMP) in an important supply chain is to be implemented. The level of implementation of GMP in the lobster supply chain in Lombok is unknown. Therefore, a gap analysis is needed for the application of GMP in the lobster supply chain in Lombok. A gap analysis is a process comparing two different situation so that we can formulate a solution to bridge the different (Ritchey, 2013).

\section{METHOD}

GAP Analysis Assess based on Decree of the Minister of Maritime Affairs and Fisheries Number 2 of 2007 concerning the method of good fish cultivation or Good Aquaculture Practice (GAP), Indonesian National Standard (SNI) 7792: 2013 for Good Handling Practice (GHP) at the fishing catcher level, and SNI 4488.3: 2011 for Good Handling Practice (GHP) at the container level, assessment of GAP and GHP related to lobster transportation is then used to describe the application of Good Transportation Practice (GTP) in the supply chain descriptively

\section{DISCUSSION}

\subsection{Lobster Handling and Application of Good Aquaculture Practice (GAP) at Enlargement Fisherman Level}

Handling lobster at the level of enlargement consists of five stages. First, enlargement fishermen purchase seeds according to their needs, KJA capacity, and financial capacity. Seeds are purchased from seed catchers in Batunampar, Awang, Bumbang and Gerupuk areas. Enlargement fishermen who lack capital can also buy seeds in the reservoir. The consequence of the purchase in the container is the sale after harvest must be carried out in the same container. Next, the seeds purchased were kept in one hole measuring $6 \times 3 \times 3 \mathrm{~m} 3$ for two months. Enlarged fishermen call this process a quarantine process before being stocked into a maintenance pit. Seedlings are given one glass of $220 \mathrm{ml}$ rebon shrimp feed. Feeding is done once, morning or evening. The average number of seeds maintained in one KJA unit reached 694.

Furthermore, the seeds that have been quarantined for 2 months are sorted first. Sort it so that the lobsters that are stocked in the maintenance pit are uniform in size and do not have a striking difference. The lobster is then stocked into a $3 \times 3 \times 3 \mathrm{~m} 3$ maintenance hole. Maintenance is carried out separately with a stocking density of $100-125$ tails. The feed given at this stage of maintenance is trash fish cut to a size of $1-2 \mathrm{~cm}$. The size of the pieces of trash fish is adjusted to the size of the lobster that is increasing every month. An alternative feed for lobster if there is no trash fish is a rice slug. Feeding is done twice a day, in the morning or evening. Some fishermen also provide feed once a day.

Harvesting is carried out after 12 months of maintenance starting from the purchase of seeds. Harvesting can be done by enlarging fishermen or collectors who buy lobsters. The harvesting process at KJA by container is sorting, stunning, 
weighing and packaging. Direct purchase by the container makes it easier for fishermen to enlarge in selling their crops and the quality is more maintained. Harvesting carried out by fishermen enlargement has the disadvantage that lobster is only placed in a plastic bucket container during distribution to the container. The entire process carried out by fishermen enlargement is shown in Figure 1.

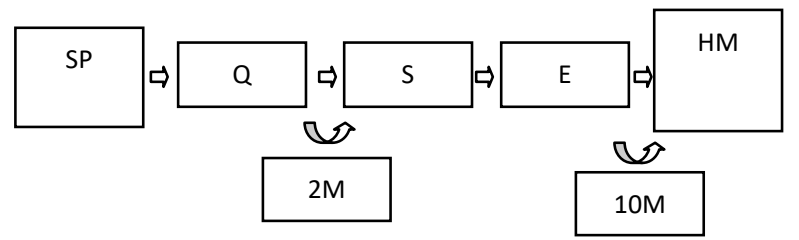

Figure 1 Process carried out by lobster enlargement fishermen

Image Description:

$\begin{array}{ll}\text { SP } & \text { : Seed procurement } \\ \text { Q } & \text { : Quarantine } \\ \text { S } & \text { : Sorting } \\ \text { E } & \text { : Enlargement } \\ \mathrm{HM} & : \text { Harvesting and marketing } \\ 2 \mathrm{M} & \text { : Two month process } \\ 10 \mathrm{M} & \text { : Ten month process }\end{array}$

The application of Good Aquaculture Practice (GAP) to lobster enlargement is very important to maintain the quality of lobster. The application of GAP to fishermen enlargement in Lombok is still quite a lot of non-conformity. The results of the assessment of nonconformities are shown in Table 1. Nonconformities in fishing enlargement consisted of 14 minor deviations and 16 major deviations.

Teble 1. Incompatibility handling on enlargement fisherman

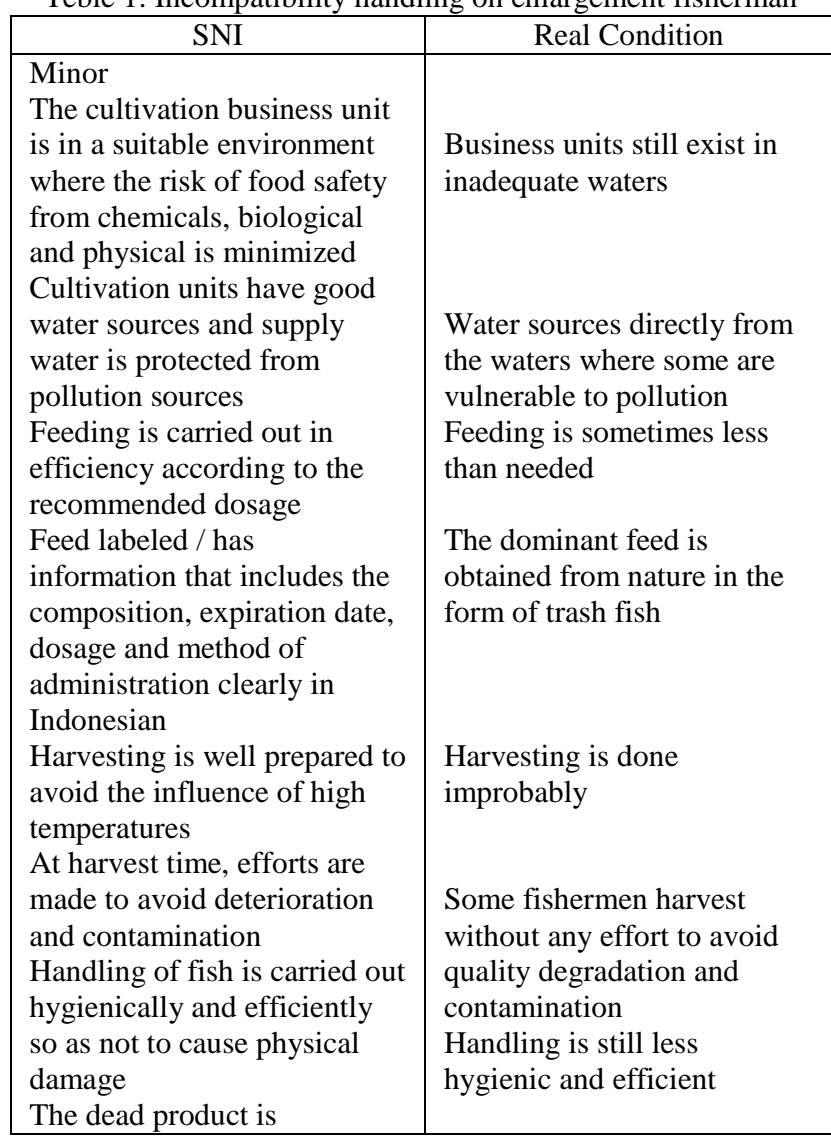

immediately cooled and the temperature is close to $0^{\circ} \mathrm{C}$ in all parts

The product temperature during transport is close to temperature $\left(13{ }^{\circ} \mathrm{C}-15^{\circ} \mathrm{C}\right)$ in all parts of the product Live lobsters are handled and maintained in conditions that do not cause physical damage or contamination

Recorded the type and origin of feed (manufacturer's feed) and raw materials for fish (for homemade feed)

Record keeping of use of fish drugs, chemicals and biological materials or other treatments during the maintenance period

Record water quality (source water, supply water, maintenance water and liquid waste) as needed

Record keeping of disease events that might have an impact on food safety of fishery products

Major

The cultivation business unit has a design and layout that can prevent cross

contamination

Toilets, septic tanks, warehouses and other facilities are separate and do not have the potential to contaminate aquaculture products

The cultivation unit has a liquid or solid waste disposal facility that is placed in the appropriate area

Efforts to filter water or settling are carried out and ensure the quality of water that is suitable for cultivated fish

Monitor source water quality regularly to ensure the quality of water that is suitable for cultivated fish

The seeds are stocked in healthy conditions and come from certified hatchery units and do not contain dangerous diseases or fish medicine.

Fish feed used has a registration number / certificate issued by the Director General or a guarantee letter from a competent institution Medicines for fish, chemicals and biology are stored properly according to specifications.
No temperature drop is approached to close to $0{ }^{\circ} \mathrm{C}$

Some fishermen carry out transportation without trying to maintain temperature It still allows physical damage

There is no recording of the type and origin of raw materials

No storage of records of drugs, chemicals and other biological materials is carried out

There is no water quality record

There are no records of disease events

The design and layout still allows cross contamination

Toilet and warehouse are not separate

Do not have liquid or solid waste disposal facilities

Water directly from the waters

Water quality monitoring is not carried out

Seeds not certified

Direct food is obtained from nature

No storage is carried out according to specifications

Tests are not carried out to detect drug and chemical residues

Ice is not from an approved 


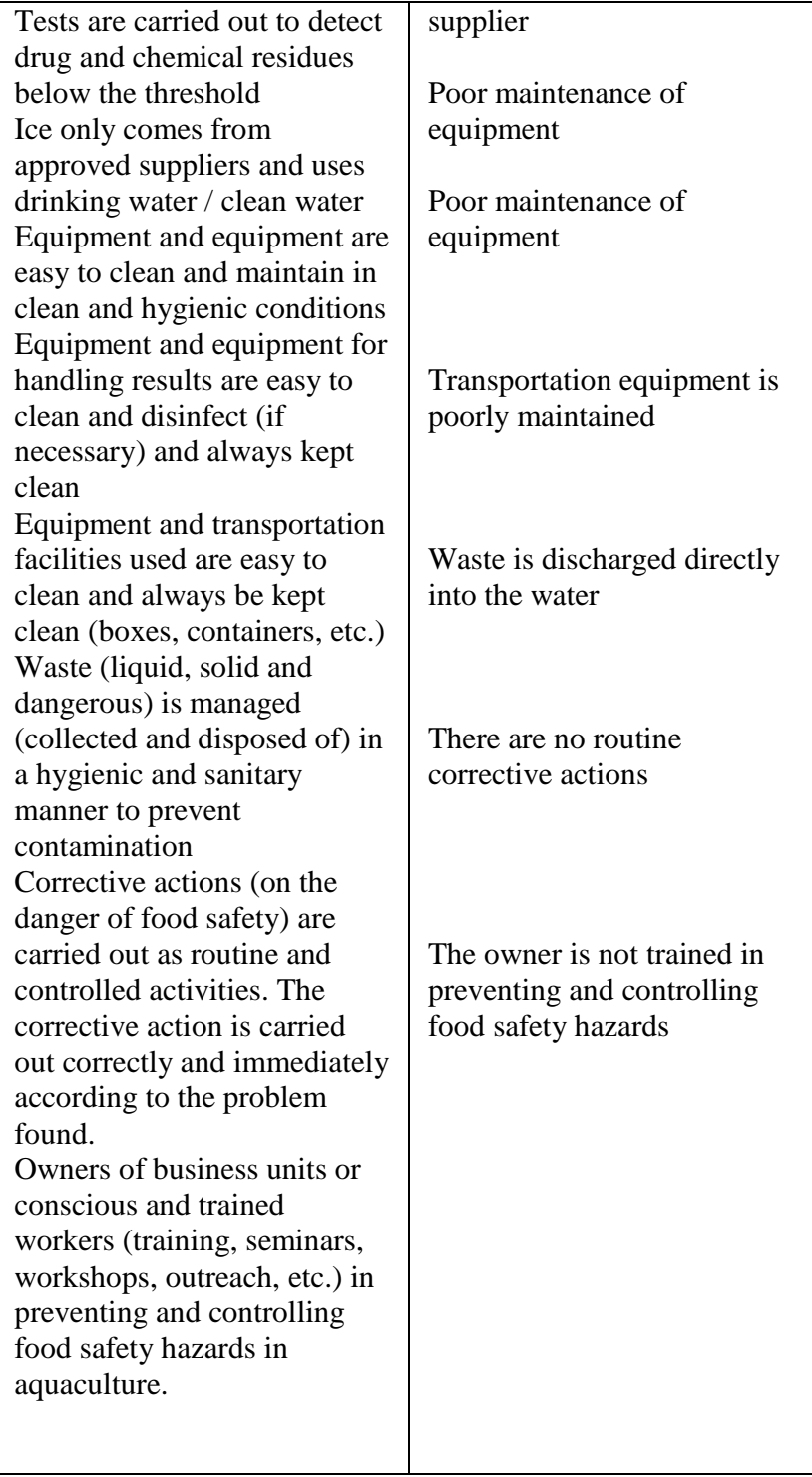

\subsection{Lobster Handling And Implementation of Good Handling Practice (GHP) at Catcher Fisherman Level}

Handling lobster at the fishing catcher level is done simply. Handling is carried out, namely: handling before arrest, handling during arrest, and handling post-arrest. Handling before the arrest is done is the preparation and inspection of equipment. Next, handling when catching is done when removing the net at a depth of 25-40 meters. The net is released in a circle around the coral reef. Then the catch is brought up and placed in styrofoam containers containing fine sand. The catch collected in styrofoam is distributed to reservoirs by land.

The application of Good Handling Practice (GHP) in lobster fishing in Lombok is very important to maintain the quality of lobsters. Lobster that has good quality will provide more benefits than lobster that is less qualified. The incompatibility of GHP implementation with catching fishermen is shown in Table 2. Deviations carried out by lobster fishermen in Lombok consist of 5 major deviations, and some aspects that are not available in terms of ship design and layout. This is because most lobster catchers use small capacity boats or boats. Lack of capital causes fishermen not to be able to buy or rent larger vessels.

Table 2. Incompatibility on catcher fisherman

\begin{tabular}{|l|l|}
\hline \multicolumn{1}{|c|}{ SNI } & \multicolumn{1}{c|}{ Real Condition } \\
\hline $\begin{array}{l}\text { Minor (Not Available) } \\
\text { Ship space used for direct } \\
\text { contact has a design that can } \\
\text { prevent contamination. }\end{array}$ & $\begin{array}{l}\text { Has no design that can } \\
\text { prevent contamination }\end{array}$ \\
$\begin{array}{l}\text { Awake handling design of } \\
\text { disease-spreading animals }\end{array}$ & $\begin{array}{l}\text { It still allows interference } \\
\text { from disease-spreading } \\
\text { animals }\end{array}$ \\
$\begin{array}{l}\text { Walls and floors are made of } \\
\text { Does not have a design as }\end{array}$ \\
\hline
\end{tabular}

material that is smooth, does

not absorb water and is easy

to clean

The ship is designed so that

laundry waste flows directly

into the sea and there is no hot

water

Minor

Equipment consists of: container (hatch or insulated

box), aerator, salinometer,

thermometer, water pump.

All equipment and equipment

used in handling live lobsters

have a smooth and flat

surface, do not peel, do not

rust, do not constitute a source

of contamination of

microorganisms, are not

cracked and are easy to clean.

Measurement of clean

seawater parameters

according to the parameters of

live lobster media

Salinity and temperature of

water are maintained

according to lobster habitat

The number of lobsters is

adjusted to the capacity of the container

\subsection{Handling of Lobster and Application of Good Handling Practice (GHP) at Container Level}

The container in Lombok has implemented GHP well. This condition should be maintained and developed so that lobster containers in Lombok can directly export lobster. The results of the assessment of nonconformities in containers are shown in Table 3.

Table 3. Incompatibility on container

\begin{tabular}{|l|l|}
\hline \multicolumn{1}{|c|}{ SNI } & \multicolumn{1}{|c|}{ Real Condition } \\
\hline $\begin{array}{l}\text { Minor } \\
\text { The shelter business unit has } \\
\text { a design and layout that can } \\
\text { Major cross contamination }\end{array}$ & $\begin{array}{l}\text { The design and layout still } \\
\text { allows cross contamination }\end{array}$ \\
$\begin{array}{l}\text { Shelter business units have } \\
\text { liquid or solid waste disposal } \\
\text { facilities placed in the }\end{array}$ & Disposal directly to the coast \\
appropriate area & or waters around the shelter \\
\hline
\end{tabular}


The container gets the lobster in two ways, namely: first, the lobster is delivered directly to the shelter by fishermen catching or fishing enlargement, the container also gets lobster by coming directly to harvest with the owner of KJA. Handling in both ways of getting lobster supplies is no different.

Handling carried out by container consists of several stages, namely: sorting, stunning, weighing, packaging, and distribution of sales. Sort is done to find out the number of lobsters with different types. Separation of lobster based on the type is based on the desire of the customer. Stuning is done by placing lobster in a plastic container filled with water. The water temperature is lowered slowly to $10-15^{\circ} \mathrm{C}$. The lobster is soaked for 15 minutes until it faints. Fainting lobsters are dried with fine sand. Then the lobster is weighed and packaged using newspaper and then placed in styrofoam containers with a capacity of $18-20 \mathrm{~kg}$. Styrofoam is equipped with ice cubes which are packed with plastic bottles and placed in all four corners. The styrofoam cover is glued with duct tape and then weighed. Next styrofoam is given a label to mark the contents of the type, weight and origin and destination of lobster delivery.

The results of the general assessment of nonconformities in the three main lobster supply chain actors are shown in Table 15. The application of GAP at the level of fishery enlargement is included in the fairly good category. The application of GHP at the catcher level is included in the fairly good category. The container is included in the very good category in the application of GHP.

\subsection{Good Transportation Practice (GTP) In Lobster Supply Chains in Lombok}

The application of Good Transportation Practice (GTP) is needed in every process of transferring lobster from one actor to the next. The application of GTP at the catcher level is quite good because lobsters are packed using styrofom and given coolers in the form of ice cubes in a bottle container measuring $1.5 \mathrm{~L}$. The application of GTP at the fishing level enlargement still needs improvement. Transporting lobsters to containers using inadequate equipment is still found in Lombok. Poor transportation only uses plastic containers which are sometimes not closed. Handling during this kind of transportation is found when enlargement fishermen sell not much. If sales are carried out in large quantities, the container will take directly to KJA.

Transportation carried out by containers has implemented good GTP. The procedure used has followed SNI 4488.2: 2011 and SNI 4488.3: 2011. Packaging is done with Styrofoam which has been given ice cubes so that it stays cool during transportation. The amount of ice cube used during transportation is 4 bottles of drinking water measuring $1.5 \mathrm{~L}$ in each corner of Styrofoam. The capacity of each styrofoam reaches $18-20 \mathrm{~kg}$ with the number of lobsters $72-85$ tails with an average weight of 200-250 gr.

The delivery time from the container location to the airport is around 1 hour. Shipping using ordinary cars without special insulation. The time during shipping on the plane takes 1-2 hours.

\section{CONCLUTION}

The application of Good Aquaculture Practice (GAP) at the level of enlargement fisher and Good Handling Practice (GHP) at the level of catchers is included in category $\mathrm{C}$ or quite well. In the same case the collectors level is in category A or very good. The application of Good Transportation Practice (GTP) in lobster supply chain in Lombok is quite well. However, improvements in the application of GAP, GHP, and GTP are required. Improvement in GTP is included in improvement of GAP and GHP.

\section{ACKNOWLEDGMENTS}

Our thanks to all sponsor for this research.

\section{REFERENCES}

[1] [BSN] Badan Standardisasi Nasional. 2011. SNI 4488.2:2011. Lobster (Panulirus spp) hidup untuk konsumsi-bagian 2: persyaratan bahan baku. Jakarta (ID): BSN.

[2] [BSN] Badan Standardisasi Nasional. 2011. SNI 4488.3:2011. Lobster (Panulirus spp) hidup untuk konsumsi-bagian 3: penanganan. Jakarta (ID): BSN.

[3] [BSN] Badan Standardisasi Nasional. 2013. SNI 7792:2013. Penanganan ikan di atas kapal - lobster hidup (Panulirus spp). Jakarta (ID): BSN.

[4] Jones CM, Long NV, Hoc DT, Priyambodo B. 2010. Eksploitation of puerulus settlement for the development of tropical spiny lobster aquaculture in the Indo-West Pacific. J Mar Biol. 52(2):292-303.

[5] [KKP] Kementrian Kelautan dan Perikanan. 2007. Keputusan Menteri Kelautan dan Perikanan Republik Indonesia Nomor KEP.02/MEN/2007 tentang Cara Budidaya yang Baik. Jakarta (ID): KKP.

[6] [KKP] Kementrian Kelautan dan Perikanan Republik Indonesia. 2012. Statistik ekspor hasil perikanan 2011 buku I. Jakarta (ID): KKP.

[7] Putro S. 2008. Peran mutu dalam menunjang ekspor udang nasional. Squalen. 3(1): 1-6.

[8] Ritchey, Tom. 2013. Morphological Gap-Analysis Using GMA to Find The Delta. Acta Morphologica Generalis. 2(2). 